\title{
Business Performance and Strategic Management Options in Hospitality: The Case of Lisbon City
}

\author{
Sérgio Borges $^{1} \&$ Nuno Gustavo ${ }^{2}$ \\ ${ }^{1}$ Lusófona University-University of Humanities and Technologies, Lisbon, Portugal \\ ${ }^{2}$ Estoril Higher Institute for Tourism and Hotel Studies, Estoril, Portugal \\ Correspondence: Nuno Gustavo, Estoril Higher Institute for Tourism and Hotel Studies, Av. Condes de \\ Barcelona, 2769-510 Estoril, Portugal. E-mail: nuno.gustavo@eshte.pt
}

Received: June 29, 2015

doi:10.5539/ijbm.v10n9p33
Accepted: July 20, 2015

Online Published: August 22, 2015

URL: http://dx.doi.org/10.5539/ijbm.v10n9p33

\begin{abstract}
This research addresses the growing hotel market phenomenon where two dominant strategic management models coexist: Hotel chains and independent hotels. In this context, this research intends to study the main strategic and operational management differences of these two business models and their differences in terms of business performance.

The case study presented focuses on the city of Lisbon (Portugal) with a total sample of 114 hotels surveyed. Taking the Balanced Scorecard methodology as reference for the empirical analysis, the several associated indicators allowed us to compare and understand the differences in performance between the hotels integrated in international chains and the independent ones, or those belonging to small local hotel groups. The SPSS 20.0 version was used to carry out the research analysis.

If, on the one hand, the empirical evidence points to the fact that units integrated in hotel chains have more standard operating procedures and a more complex management structure, on the other, with respect to various financial indicators (Gross Operating Profit, Room Profit and Food \& Beverage Profit, etc.) there were no significant differences between the two types of hotel management model.
\end{abstract}

Keywords: hotel chains, independent hotel, management, performance, balanced scorecard

\section{Introduction}

The current prominence of the tourism industry in the global economy is easily understood when one looks at the overwhelming growth characteristics that this sector has been presenting over the past decades.

According to Buhalis and Costa (2006), in the 70s, the number of international arrivals increased by 675 million compared to the 50s. In 2012, this number amounted to 1.035 million (UNWTO, 2013), largely exceeding the 940 million international arrivals in 2010 (UNWTO, 2011). According to the existing projections, it is expected that by 2030 the number of arrivals reaches 1.8 billion, growing at a rate of $3.3 \%$ per year, i.e., the average number increasing by about 43 million annually (UNWTO, 2011). The reasons for this increasingly higher rate growth relate mainly to the enormous transformations that occur both at the supply and the demand level, which are leveraged by a socio-economic context in constant change, which as Evans (2015) points out, has a decisive impact on any industry. In a world that is now more global, with an increasingly comprehensive technological drive, where interconnections multiply, where consumer habits are modified at a more accelerated pace, where structural changes occur at the level of employment, family and socio-economics, an effective response from the industry and the tourist and hotel organizations is required, and that response necessarily involves innovation when maximizing resources, the creation of new business models, the personalization of consumer experience and the increase of quality standards of services rendered, among other things.

\section{Literature Review}

\subsection{Tourism and Hospitality: A Changing Market}

Tourism is nowadays inevitably forced to undergo several changes and adjustments regarding its morphology, incorporating, on the one hand, the benefits of globalization, and influencing and encouraging the globalized way of existence, on the other (Evans, 2015; Pla-Barber, \& Ghauri, 2012). "The globalization process will 
continue, because tourism is a global business, a world industry without boundaries, open to all changes and improvements. Humans as travelers want to feel safe, free and at home, no matter where they are. Tourism will strive to achieve a balance between the two dissimilarities of unification and diversification, and to adopt the positive features of globalization, while emphasizing particularities and attractions through localization" (Holjevac, 2003, p. 131).

Most likely, this activity will be perceived as a "free market" across borders where the globalizing aspect of today's societies works as a relevant catalyst for tourism activities. These, indeed, are increasingly managed by global reservations computer systems, offered as a final product disputed in an international competitive environment, where large tourism companies increasingly dictate more forcefully the economic rules and the way dividends are distributed within the tourism sector.

Also the hospitality sector, the cornerstone of the tourism activity, is increasingly forced to submit to metamorphoses and adjustments imposed by a socio-economic situation with no precedents until recently, with regard to their competitiveness dynamics and global nature. This sector has been inevitably shaped by the growing awareness of the systemic paradigm and the benefits of maximizing network interactions. The reality of existing in network in the market has been increasingly exploited by the industry stakeholders, seeking mainly to consolidate their position in an increasingly competitive market. In effect, there is in this market a permanent threat regarding the emergence of new competitors, involving the high possibility of more attractive substitute products arising, where the negotiating power of customers and suppliers grows at every step and competition between rivals reaches suffocating magnitudes (Porter, 1999). In this growing competition scenario, several phenomena have occurred thus complexifying the reality of network operation, and, at various moments, its unfair nature motivates regulatory interventions by government institutions in those cases. An example of this is the appearance of oligopolies and monopolies as a result of the successive acquisition/merger (horizontal or vertical) processes (Cunill, 2006). According to Cunill (2006), the creation of monopolies, either of horizontal or vertical growth, inevitably leads to the strangulation of the competition, which in turn reduces the sector's competitiveness, with special effect on medium or small independent hotel units, especially when they are not part of a renowned group or chain. The same result occurs when several hotel chains agree among themselves on the prices charged to the customers. This economic oligopoly structure protects the players of a certain sector and these hold equivalent market shares. Hotel chains are mainly the result of an asset light strategy, supported in a branding strategy where franchising and management contracts are dominant. The main economic and management principles behind this development strategy are economy of scales, resource sharing and centralized management (Chen \& Dimou, 2005; Whitla et al., 2007; Alon et al., 2012).

Although these scenarios are likely to emerge, they are virtually neutralized by the characteristics of a market structure that is based on monopolistic competition. In this reality, the products presented differ from each other and the number of either competitors or customers reduces the margin for negotiating agreements on prices of products and services. However, according to Enz (2005), one of the global factors resulting from the growing creation of dominant companies and oligopolies is the consolidation of the industry. This means that, for example, we are witnessing a growing trend of merger or acquisition among large companies with considerable market power that are likely to be located in the same industry, but in different sectors that intersect. This results in an increased power to raise market indirectly through a greater accessibility and exchange regarding the customer portfolio held by the different companies.

Nonetheless, even in a monopolistic competition scenario, hospitality companies of a certain size that have a chain organization inevitably seem to be in the spotlight regarding the market dominance, since they have a higher ability to access and coordinate large flows of resources, products, people and information (Bartlett \& Ghoshal, 2002), thus materializing the culture of the global "informational" economy (Castells, 1999).

The fierce competition scenario, however, and a web whose increasing complexity is implemented globally seems to leave little space for independent hotel units (hotel units directly management by its owner, with a less formalized managed structure, as well as not associated with an internationally renowned brand or that are not part of large economic structures) (Chen \& Dimou, 2005; Whitla et al., 2007; Alon et al., 2012). For instance, the simple fact that they do not have a brand that is shared by various units places, from the outset, this type of hotels in a major disadvantage, since there are brands in the opposite vector that, according to Enz (2005), influence the market more effectively, quickly and economically, holding a greater negotiating power with the communication channels available. Thus, the hospitality market in the postmodern economic environment appears to privilege larger organizations whose strategies undergo a massive presence in as many countries as possible. Given its large size structure and the ease of access to resources, multinational chains and their units appear to be more prepared for an increasingly volatile economic environment where the high pace for the emergence of new trends is 
increasing and the need to follow and maximize them becomes increasingly apparent. Among the many ways of existing in network that contact in the information age, there seems to be an advantage for the intrinsic networks linking the different units of the same brand and the maximization these reach given the available resources. On the other hand, the lightness of standalone units and the shorter networks, and therefore possibly less obstructed, may signify a faster ability to adjust to market volatility, since a less complexified structure leads inevitably to less entropy in the organization and thus to a greater agility in view of the desired changes.

Changes are definitely a very common feature in today's markets and the hospitality sector does not present itself as an exception to the rule. On the other hand, the reality of the existence in network is, as previously presented in this paper, an unavoidable fact that reveals itself globally to all postmodern industries and their sectors. With regard to hospitality, this is well combined with such a scenario. The focus of this paper is to identify what kind of hospitality organization is better prepared to cope with this reality due to its own characteristics.

In an increasingly unstable economic environment (Shiller, 2008; Crotty, 2008), the hospitality players feel the pressure that comes from increasing fixed costs, holding increasingly disputed market shares thanks to the proliferation of new competitors. In this sense, the robustness of the hotels integrated in multinational chains invariably differs from the economic size of independent hotel units.

\subsection{Hospitality, Business Models and Operational Performance}

Constant change is definitely a characteristic of today's societies and markets. The hospitality sector is not the exception to the rule. On the other hand, the reality of the existence in network is, as previously mentioned, an unavoidable globally present in all postmodern industries and their sectors. According to Crossan and Berdrov (2003) and Zahra and George (2002), in recent years, many business organizations have become aware that due to intensifying competition, globalization and technological "explosion", elements such as organizational learning and the ability of knowledge creation and innovation have become unavoidable competitive advantage factors for companies.

Thus, also today's hospitality organizations have seen their negotiating territory adopt unprecedented configurations both on the side of consumption and the competition. This fact, by translating into considerably high rate changes has forced the players, in the hospitality sector, to take an increasingly active role in order to find solutions that ensure their sustainability in the market. However, the diversity of characteristics presented by the sector players shows a very asymmetric reality in terms of the competition dynamics that exists in this market. Thus, it sharpens the curiosity of those interested in the multiplicity of phenomena that may manifest themselves as a response of these organizations to the business challenges. According to Metcalfe (2005), this attitude of constant reinvention of the hoteliers is justified by the intimate relationship between the need for innovation and the characteristics of modern capitalism.

Modern economy to which Metcalfe (2005) refers is based on an unprecedented competitiveness paradigm. From the perspective of this paper, the concept of competitiveness is seen in the same way as that mentioned by Barney (1991), where the competitive paradigm consists of the implementation, by a certain company, of a strategy that creates value and effective growth compared to direct or potential competitors that may enter the market in the short to medium term. The pressure that it makes on the business dynamics of companies that compete in the market is not compatible with passive postures or postures less attentive to the internal sectorial context, or the external macro context that influences indirectly, but also effectively, each player's results in the market in which it competes. According to Grant (1996), the growing turbulence of the exterior business environment has led to the polarization of the issue increasingly focused by researchers and businessmen: The resources and organizational skills. The author argues that these are the two main elements responsible for the sustainable continuity of organizational competitiveness. Grant (1996) also argues that organizational competitiveness requires the acquisition of idiosyncratic resources that are not easily transferable or replicable. According to Barney (1991), the strategic resources are allocated heterogeneously to the different organizations that are part of the economic landscape, and this diversity becomes responsible for the performance differences among companies with regard to their competitive advantages.

The resources allocated to a specific company correspond to material goods of any type, capabilities, organizational processes, company attributes, information, knowledge, etc., for which the corporation holds full control and access by making use of them in implementing strategies that result in an improvement of its efficiency and effectiveness (Daft, 1983). According to Barney (1991), in the common language of the traditional strategic analysis perspective, the resources of a company are seen as forces that the company may use with a view to carry out its strategies successfully. The same author also divides the concept of resources into three main groups, namely: Physical resources, human capital resources and organizational resources. In the first vector, we have the 
physical technology used in a given company, its facilities, the equipment of the company to carry out its activity, the geographical location and the access to raw materials. The elements related to human capital such as training, experience, decision-making ability, intelligence, relationships and contributions of management and workers of the company are located in the second quadrant. Lastly, the organizational resources relate to the hierarchical structure of the company, to its formal and informal planning, to the control of the activities, the coordination of internal active systems, as well as to the informal relationships among groups within the organization and between the organization and the elements that make up its external environment.

In short, the competitive advantages of a certain market position are the result of a combination of factors that interact with two main dimensions: The demand side, where the productive activities of a company must respond objectively to market needs, and the supply side, where the organizational awareness can not only respond to market needs, but needs to do so more effectively and efficiently than the rest of the competitors. The strategic management of these factors will influence the company's potential for success in the market in which it competes. According to Enz (2005), the companies that carry out a specific strategic management model tend to get better results when compared to companies that do not do it. This vision supports the postulate by Cunill (2006) which makes clear that a well-formulated strategy stands out as crucial to the achievement of organizational success.

Under this topic and also according to Enz (2005), there are three main perspectives with regard to strategic management models: The traditional perspective, the perspective based on resources allocated to the company and the perspective based on the organization's stakeholders. The strategic management traditional perspective postulates that any business organization must focus on goals that include two basic elements: a way to maximize the organizational strengths and the opportunities of the external environment; and a means to neutralize or overcome any type of weakness within the organization and possible threats coming from the context where the company is located. The perspective based on organizational resources maintains that the focus of attention of those who manage the company should be in the acquisition of the best organizational resources, since their strategic management will lead to better results. The best resources are the ones valued in the market and held by a small number of companies, and they are not easily replaced. Lastly, the strategic management perspective focused on the stakeholders argues that the organizational resources closely depend on the relationship established between the organization and its external environment, and this should be the focus of attention. As an example, Enz (2005) mentions that, with regard to financial resources, the success will be greatly influenced by the qualitative working relationships with the financial intermediaries. In what concerns the human capital, its development will be also linked to effective management of organizational stakeholders. Finally, with regard to resources, they reflect an organizational understanding of the society expectations and the connections established with the external environment.

Stonehouse et al. (2004), dedicated to the study of strategic management, more specifically the relationship between the procedures used by business organizations and the globalization phenomenon, also argue the competitive advantages assigned to the organizational implementation of management adjusted to the companies' characteristics and situation. These authors make some relevant considerations regarding the concept of strategic management. Firstly, they argue that the competitive advantage results from innovative knowledge superior to the competitors'. In addition to that, learning and organizational knowledge management are vital for sustaining that competitive advantage. Thus, the strategic formulation carried out by the company, although planned, must allow space for changes resulting from the organizational dynamics. Moreover, Stonehouse et al. (2000) argue that the competitive advantage results either from internal core skills or changes in the external business environment conditions. Finally, the authors state that the competitive advantage is not solely generated by competition behaviours among business organizations disputing the same market, but also by a collaborative behaviour with external elements.

\section{Research Problem}

Thus, as previously mentioned, the hospitality market is increasingly demanding, volatile and overcrowded at the global level, despite regional differences that may be identified, namely between East and West. In this scenario, the existing competitiveness requires greater attention to detail that determine not only the effectiveness but also the efficiency of the production process, with every detail contributing to the difference between failure and success. The careful choice that the hotel unit makes with regard to the management strategy of its resources and skills launches the foundations for the theme on which this work finds its study object.

The ability to provide the customer with a differentiated product/service that attracts the most varied market segments is an increasingly demanding challenge. The different types of strategy are increasingly being tested by 
the hospitality players with a view to gain a competitive advantage over abundant rivals disputing the market.

Several studies suggest, through empirical evidence, that there is a stark correlation between the choice of the organizational strategic management model of hotel units and the actual performance they achieve (Sainaghi, 2010). Based on the research already developed on the topic, it seems that in a complex set of factors involved in determining the performance of the hotel units, the strategic management habits play an important role influencing the results that the business organization may get in its business dynamic. It is therefore relevant to deepen then knowledge about the reality of the strategic management models in the hospitality sector and its seemingly close relationship with the performance they give to hotels applying them.

On the other hand, in a reality that is increasingly interconnected by the way of existence in network, the business settings that have a wingspan that allows for the coexistence of their units seem to provide them with differentiated advantages in terms of results when compared to independent organizations that are not part of larger structures (Rushmore, 2004; O'Neill \& Xiao, 2006; O'Neill \& Mattila, 2004; Damonte et al., 1997). Nevertheless, the lack of linearity on the topic is encouraged by empirical data originating in research that presents opposite evidence (Miyeal-Higgins, 2006; O’Neill \& Carlback, 2011).

A similar oscillation effect in the performance of the hotel unit seems to be produced also by the rating of the product/service quality it presents (Israeli, 2002). The lack of consensus with regard to performance differences generated by the various strategic management approaches carried out by the hotel units thus opens the opportunity for research and analysis of the topic focused by this paper. Therefore, it is relevant to deepen the differences in terms of the strategic management habits of hotel units, according to the type of service they provide and binding characteristics with a view to the results achieved in the market they are part of.

Thus, this study aims to understand the operational and performance differences in hotel units according to their standalone strategic model or strategic model integrated in chains/economic groups. The study focus on units with different characteristics. These relate not only to the typology of service they present (hotel classification), but also to the fact that these establishments are or are not part of national or multinational business structures.

$\mathrm{We}$, therefore, intend to explore the influence that these characteristics have in the choice of management processes and, consequently, in the operational performance of hotel units.

\section{Hypotheses}

This research aims to understand with more empirical accuracy the market survival behavior of independent units in a context where there is an increasing corporate membership tendency (O'Neill \& Matilla, 2004) and the use of the advantages brought by this business model. This maximization of existing in a network seems to produce advantages to the units applying it, apparently leaving little room for players that dispute the market through independent hotel units. The importance that the networks have taken in contemporary society is striking, which has inevitably been reflected in the increasingly competitive reality in the hospitality sector. It is, therefore, urgent to analyze the competitive coexistence phenomenon in a market environment, among units with corporate bonds and units that do not have that advantage conferred by the network configuration.

In this regard, the robustness of the hotels that are part of multinational chains appears to be different from the economic dimension of the independent hotel units. This leads us to the following question:

"Do the management practices and the performance of independent units show significant differences when compared to those used by international hotel chains?"

While it is a fact that transnational companies hold a great advantage since they have an international distribution of the resources they use, this alone is no guarantee of success. The systemic dynamics that are characteristic of the hospitality operation, although endowed with the same goals, use diversified methodologies, which may inevitably let to very heterogeneous results.

For example, a rigorous choice of the management model to be adopted proves to be a crucial factor for business success (Chesbrough \& Rosenbloom, 2002). In this field, it may be advantageous for a small independent hotel unit to use an asset light type management model. This type of model is characterized by enhancing the inter-organizational relationships, particularly in terms of partnerships, which leads to the maximization of resources to a level impossible to achieve autonomously. These partnerships are carried out mainly through outsourcing contracts. By having a closer relationship with external elements that play a crucial role in its value chain, the company benefits from having almost no responsibility to pay for unnecessary resources, improving the ratio between the budgeted and the consumed resources (Mahalik \& Satpathy, 2011). 
Since the current economic scenario of the sector is characterized by competitiveness that requires that its players search for innovation and change constantly (Gallo \& Krupka, 2008), it is relevant to note the adjustment ability of the different hotel institutions to this reality. In this case, the research carried out by Hannan and Freeman (1989) suggests that the greater the size of an organization, the more structural inertia it has relatively to change. This fact corroborates Rosnay's (1975) systemic perspective when extrapolating the concept of entropy to social systems. According to the author, the larger the system, the more degraded energy it needs to expel. Therefore, more resources are used in the control of unwanted effects of improper energy, without being concentrated to absorb the signals of the environment. In this perspective, small hotel units seem to find it easier to adjust to changes in the surrounding context, thus having an advantage when compared to large hotel chains.

These dimensions, combined with the different approaches that can be used by the different hotel units, with regard to human resources policies, financial management and marketing strategies, present themselves as the main research lines that will be the subject of attention of this paper with a view to satisfactorily answer the initial question. In this context, this research intends to analyze these factors and understand how they can be the advantage elements for the competitiveness of micro-hotel units of an independent nature. Accordingly, we have systematized two hypotheses of the study in question.

H1: Independent hotel units have a strategic and operational management model of an eminent networking functional nature.

This hypothesis is defined taking into account the context of the network social reality where business organizations are integrated and the unavoidable nature that network interactions take nowadays. On the other hand, the networks established through the hospitality activity multinational corporations seem to provide these units with a global scale range, thus the formulation of a second hypothesis.

H2: A strategic management model of international hotel chains and the preference for scale economies and knowledge.

\section{Method}

This research intends to study the main strategic and operational management differences of these two business models and their differences in terms of performance.

The case study presented focuses on the city of Lisbon (Portugal) with a total sample of 114 hotels surveyed.

This research was supported by the application of a questionnaire survey to the managers of hotel units taking the Balanced Scorecard methodology as reference for the empirical analysis (Sainaghia et al., 2013; Phillips \& Louvieris, 2005; Kaplan \& Norton, 1996).

The definition of the number of hotels that make up the designed sample respected the proportion of their representativeness in the universe following the percentage proportions of the different typologies of hotel units in the city of Lisbon. However, one star hotels and hotels with other unofficial categories were excluded since there is not such an offer at the level of hotel chains. Thus in what concerns the sampled hotel units classification, 17 of them are five star hotels (14.9\%), 47 are four star hotels $(41.2 \%), 32$ are three star hotels $(28.1 \%)$ and 18 are two star hotels (15.8\%).

The application of the questionnaire surveys was carried out face-to-face and took place between 20 March and 30 April. A pre-test was conducted between 15 January and 15 February. Data analysis was carried out using the SPSS version 20.0.

\section{Results}

\subsection{Sample Characterization}

In the surveyed hotels, there was a minimum number of 18 rooms and a maximum of 577 rooms. The distinction in the number of rooms according to the typology of hotel showed that two star hotels $(\mathrm{N}=18)$ had an average number of rooms of $81.3 \pm 57.3$; three star hotels $(\mathrm{N}=32)$ had an average number of rooms of $100.5 \pm 61.4$, four star hotels $(\mathrm{N}=47)$ had an average of $132.6 \pm 109.3$ and five star hotels $(\mathrm{N}=17)$ had an average of $208.4 \pm 134.2$. 
Table 1. Number of rooms according to the typology of hotel

\begin{tabular}{lllll}
\hline & Typology & Average \pm Standard Deviation & Minimum & Maximum \\
\hline & $* *$ & $81.3 \pm 57.3$ & 18 & 211 \\
& $* * *$ & $100.5 \pm 61.4$ & 30 & 263 \\
Number of Rooms & $* * * *$ & $132.57 \pm 109.3$ & 18 & 577 \\
& $* * * * *$ & $208.41 \pm 134.2$ & 50 & 517 \\
\hline
\end{tabular}

Most properties $(65 \%, \mathrm{~N}=74)$ is affiliated with some brand or partnership - hotel chain, and the independent properties are only $35 \%(\mathrm{~N}=40)$

Comparing the properties per affiliation typology, it was observed that there was the same proportion of two star hotels $(8 \%, \mathrm{~N}=9)$ and three star hotels $(14 \%, \mathrm{~N}=16)$. However, the properties of the hotel chain type showed a higher number of hotels classified as four star hotels $(30 \%, \mathrm{~N}=34)$ and five star hotels $(13 \%, \mathrm{~N}=15)$.

Table 2. Typology of hotel according to affiliation and classification

\begin{tabular}{|c|c|c|c|c|c|}
\hline & & & Hotel Chain & Independent & Total \\
\hline \multirow{4}{*}{ Typology } & $* *$ & N (\%) & $9(8 \%)$ & $9(8 \%)$ & $18(16 \%)$ \\
\hline & $* * *$ & N (\%) & $16(14 \%)$ & $16(14 \%)$ & $32(28 \%)$ \\
\hline & $* * * *$ & N (\%) & $34(30 \%)$ & $13(11 \%)$ & $47(41 \%)$ \\
\hline & $* * * * *$ & $\mathrm{~N}(\%)$ & $15(13 \%)$ & $2(2 \%)$ & $17(15 \%)$ \\
\hline Total & & $\begin{array}{l}\% \\
\text { Total }\end{array}$ & $74(65 \%)$ & $40(35 \%)$ & $114(100 \%)$ \\
\hline
\end{tabular}

\subsection{Presentation of Results}

Regarding the existence of Standard Operational Procedures, it is observed that these are mainly found in units that are part of hotel chains, in which only $5 \%(\mathrm{~N}=4)$ do not have any type of Standard Operational Procedures, and the percentage in independent hotels increases to $75 \%(\mathrm{~N}=30)$.

Among the independent units, no unit was found in the sample product that assessed the established SOP $(100 \%$, $\mathrm{N}=10)$, and of the units that are part of hotel chains most of them do not do it either $(67 \%, \mathrm{~N}=47)$. Of the properties that carry out SOP assessments, $20 \%(\mathrm{~N}=14)$ use internal assessments and only $13 \%(\mathrm{~N}=9)$ say that they use external entities to assess these procedures. As for the use given to the SOP assessments, $70 \%$ of the units $(\mathrm{N}=49)$ do not maximize the assessment results in order to improve their processes.

Most of the units that are part of hotel chains mention that the importance of SOP and LSOP is clear both in the "Back of the House" and in the "Front of the House" $(77 \%, \mathrm{~N}=57)$, as for the independent units, $25 \%(\mathrm{~N}=10)$ highlight their usefulness in the "Front Of The House" and the remaining mention there is no particular usefulness in any of the areas $(75 \%, \mathrm{~N}=30)$.

The external customer satisfaction survey tends to be more clearly used in units in integrated chains of which $76 \%$ $(\mathrm{N}=56)$ say they use this type of satisfaction survey, and only $24 \%(\mathrm{~N}=18)$ mention that they do not. The reality of independent units is opposed to this, since $73 \%(\mathrm{~N}=29)$ of the respondents do not use any type of external customer survey, and the remaining minority of units $(28 \%, \mathrm{~N}=11)$ mention they this analysis method.

In the financial field, the overwhelming majority of independent units has no standardized procedure for response timings to customers $(85 \%, \mathrm{~N}=34)$, with the remainder distributed equally between standards less than 30 days and between 30 and 40 days. However, with regard to the properties of hotel chains, most of them $(85 \%$, $\mathrm{N}=63)$ has standards for response timing to customers and the responses are less than 30 days $(51 \%, \mathrm{~N}=38)$.

According to the analysis focusing on the affiliation of the units, the mode of funding through the owners presents itself as the most frequent in both types of property, with greater emphasis on the properties that are part of hotel chains, of which $93 \%(\mathrm{~N}=69)$ use this type of process while $7 \%(\mathrm{~N}=5)$ use funding methods such as "loans". Among the independent properties, the gap between the two types of funding represents a lower expression, with $63 \%(\mathrm{~N}=25)$ using methods based on owners funding and $38 \%(\mathrm{~N}=15)$ using funding originating in loans.

The hotel units that are part of some kind of chain present a higher percentage $(73 \%, \mathrm{~N}=54)$ regarding the existence of aging policies when compared with the independent units $(18 \%, \mathrm{~N}=7)$. It was also noted that the 
units that are part of hotel groups have the same percentage in terms of adoption of aging analysis policies based on more than 60 days $(37 \%, N=27)$ and the analyzes based on other time periods $(37 \% \mathrm{~N}=27)$. The independent properties present a percentage of $13 \%(\mathrm{~N}=5)$ for the aging analysis with more than 60 days, and only $5 \%(\mathrm{~N}=2)$ choose other types of timing for the analysis of this element.

Regarding capital for investments, $22 \%(\mathrm{~N}=16)$ of the properties that are part of hotel chains assume they have some reserves for such investments while the rest, either affiliated with chains or operating independently make no type of reserve fund for the previously mentioned purpose. The trend towards funding from owners is mainly observed in hotel chains $(62 \%, \mathrm{~N}=42)$ and the loan type in independent units $(80 \%, \mathrm{~N}=31)$.

If we look at independent hotel units, there is an overwhelming majority of hotels that do not study the "return on investment" whenever they make an investment $(98 \%, \mathrm{~N}=39)$. As for the hotel, it is noted that while most units admit not to use this practice systemically, the percentage of these is rather low $(67 \%, \mathrm{~N}=48)$.

If we compare the nature of affiliation of sampled units regarding the GOP (Gross Operating Profit), we observe that $13 \%(\mathrm{~N}=10)$ of the integrated units have a GOP between $23 \%$ and $10 \%, 58 \%(\mathrm{~N}=42)$ have the same GOP values between 12 and $30 \%$ and $29 \%(\mathrm{~N}=12)$ claim to have values between $31 \%$ and $54 \%$.

As for the independent units, $15 \%(\mathrm{~N}=6)$ present this indicator between -23 and $10 \%, 55 \%(\mathrm{~N}=22)$ present figures between $12 \%$ and $30 \%$ and $30 \%(\mathrm{~N}=12)$ of these units have GOP figures between 31 and $54 \%$.

Table 3. GOP (Gross Operating Profit) percentage per affiliation

\begin{tabular}{lcccc}
\hline & & & Hotel Chain & Independent \\
\cline { 2 - 5 } GOP (Gross Operating Profit) & $\mathbf{- 2 3}$ and 10 & $(\%)$ & $13 \%$ & $15 \%$ \\
& $\mathbf{1 2}$ and 30 & $(\%)$ & $58 \%$ & $55 \%$ \\
& 31 and 54 & $(\%)$ & $29 \%$ & $30 \%$ \\
\hline
\end{tabular}

Of the units that are part of hotel chains, $38 \%(\mathrm{~N}=28)$ of them have a cost per occupied room between 7 and 17 Euros, $43 \%(\mathrm{~N}=31)$ between 18 and 25 Euros and 19\% $(\mathrm{N}=14)$ between 26 and 70 Euros. $62 \%(\mathrm{~N}=25)$ of the independent units present this indicator 7 and 17 Euros, 33\% $(\mathrm{N}=13)$ between 18 and 25 Euros and the remaining $5 \%(\mathrm{~N}=2)$ a cost per occupied room between 26 and 70 Euros.

Table 4. Cost occupied room value per affiliation

\begin{tabular}{lcccc}
\hline & & & Hotel Chain & Independent \\
\cline { 2 - 5 } Cost per occupied room & $\mathbf{7}$ and 17 & $(€)$ & $38 \%$ & $62 \%$ \\
& $\mathbf{1 8}$ and 25 & $(€)$ & $43 \%$ & $33 \%$ \\
& $\mathbf{2 6}$ and 70 & $(€)$ & $19 \%$ & $5 \%$ \\
\hline
\end{tabular}

$19 \%(\mathrm{~N}=14)$ of the units included in this sample, that are part of chains, present a room profit margin between $42 \%$ and $60 \% .60 \%(\mathrm{~N}=44)$ of the units with the same typology regarding the affiliation present rooms profit margins between 61 and $70 \%$. Lastly, $21 \%(\mathrm{~N}=15)$ of the units that are part of hotel groups present rooms profit margins between 71 and $86 \%$. As for the sample of independent units, $28 \%(\mathrm{~N}=11)$ of them present rooms profit margins between 42 and $60 \%, 60 \%(\mathrm{~N}=24)$ between 61 and $70 \%$ and $12 \%(\mathrm{~N}=5)$ between 71 and $86 \%$.

Table 5. Rooms profit margin per affiliation

\begin{tabular}{lllcc}
\hline & & & Hotel Chain & Independent \\
\cline { 2 - 5 } Rooms Profit Margin & $\mathbf{4 2}$ and 60 & $(\%)$ & $19 \%$ & $28 \%$ \\
& 61 and 70 & $(\%)$ & $60 \%$ & $60 \%$ \\
& 71 and 86 & $(\%)$ & $21 \%$ & $12 \%$ \\
\hline
\end{tabular}

As for the units that are part of chains, $30 \%(\mathrm{~N}=22)$ refer they have an $\mathrm{F} \& \mathrm{~B}$ margin profit between $-23 \%$ and $1 \%, 45 \%(\mathrm{~N}=33)$ presents margins between 2 and $15 \%$ and the remaining $25 \%(\mathrm{~N}=18)$ between 17 and $32 \%$. Of the independent units, $25 \%(\mathrm{~N}=10)$ present $\mathrm{F} \& \mathrm{~B}$ margin profits between -23 and $1 \%, 53 \%(\mathrm{~N}=21)$ say they have margins between 2 and $15 \%$ and $22 \%(\mathrm{~N}=9)$ mention margins between 17 and $32 \%$. 
Table 6. F\&B profit margin per affiliation

\begin{tabular}{ccccc}
\hline & & & Hotel Chain & Independent \\
\cline { 2 - 5 } F\&B Profit Margin & $\mathbf{- 2 3}$ and 1 & $(\%)$ & $30 \%$ & $25 \%$ \\
& $\mathbf{2}$ and 15 & $(\%)$ & $45 \%$ & $53 \%$ \\
& $\mathbf{1 7}$ and 32 & $(\%)$ & $25 \%$ & $22 \%$ \\
\hline
\end{tabular}

Regarding the aspect of Human Resources management, the analysis of results by comparison of affiliation types suggests the existence of a greater emphasis on internal recruitment by the units that are part of multinational chains. $78 \%(\mathrm{~N}=31)$ of the independent units have a maximum of $10 \%$ of managers recruited internally, $20 \%$ have an internal recruitment rate of managers between $11 \%$ and $40 \%$, with only $2 \%(\mathrm{~N}=1)$ of properties having more than $50 \%$ of managers recruited within the property. As for the units that are part of chains, $18 \%(\mathrm{~N}=5)$ of the sampling offers up to $10 \%$ of managers recruited internally and $53 \%(\mathrm{~N}=39)$ have more than $50 \%$ of the managers recruited internally.

Table 7. Managers recruited internally per affiliation

\begin{tabular}{lcccc}
\hline & \multicolumn{3}{c}{ Hotel Chain } & Independent \\
\cline { 2 - 5 } Managers Recruited Internally & $<\mathbf{1 0}$ & $(\%)$ & $30 \%$ & $78 \%$ \\
& $\mathbf{1 1}$ and 40 & $(\%)$ & $45 \%$ & $20 \%$ \\
& $\mathbf{5 0}<$ & & & $2 \%$ \\
\hline
\end{tabular}

If, on the one hand, in the scenario of the independent units there is a clear majority $(90 \%, \mathrm{~N}=36)$ of properties that do not have any type of recruitment and selection model established, on the other, in the scenario of the properties integrated in hotel chains there are $43 \%(\mathrm{~N}=31)$ applying a defined recruitment and selection model, and the remaining $58 \%(\mathrm{~N}=42)$ do not do it. The independent units with $83 \%(\mathrm{~N}=33)$ and the units that are part of with $92 \%(\mathrm{~N}=67)$ are in line with the trend of total analysis, electing the experience as the main criterion in the selection of candidates.

It is noted that, in the scenario of the independent properties, the turnover is significantly more moderate, with about $88 \%(\mathrm{~N}=35)$ of units with an annual average turnover of less than $10 \%$. In the scenario of hotels integrated in groups, the proportion of units with an annual turnover of less than $10 \%$ is $65 \%(\mathrm{~N}=47)$. The average headcount in properties affiliated in hotel chains is 46 employees, and the average headcount in independent units is slightly less than half (20 employees). With regard to the hotels affiliated in hotel chains, the average number of training hours is 32 hours, while with regard to independent units the average is 16 hours of training. The average absenteeism in units that are part of hotel groups is $7 \%$ higher than the average of the independent units which is $5 \%$.

For the data measured in the marketing dimension, it can be seen that most integrated units $(63 \%, \mathrm{~N}=46)$ present loyalty programs to their customers while the remaining $37 \%(\mathrm{~N}=27)$ do not. As for the independent units, the overwhelming majority does not have any loyalty program $(95 \%, \mathrm{~N}=38)$.

The independent units included in this survey do not have any creative department in their structure, while $18 \%$ $(\mathrm{N}=13)$ of the integrated units claim to have such department in their organization. Only $1 \%(\mathrm{~N}=1)$ of the integrated units refers it outsources the management of online presence, compared to $25 \%(\mathrm{~N}=10)$ for independent units. Most units that are part of hotel groups have newsletters $(71 \%, \mathrm{~N}=52)$, and from the perspective of independent units, only $10 \%(\mathrm{~N}=4)$ claim to use this information channel.

The average percentage of sales related to business is higher in independent properties (51\%), while the average for business in properties in integrated hotel groups is $31 \%$. With respect to the average percentage of recreational sales, units included in the hotel chains have a percentage of $66 \%$, while the independent nature properties have an average of $46 \%$ of sales for this segment.

\subsection{Discussion of Hypotheses}

To decide whether a particular hypothesis is supported by a set of data, an objective procedure is required: to reject or not to reject a hypothesis (Mann PS, 1995).

The hypothesis that the type of affiliation/partnership of the property (hotel chain versus independent) significantly influenced the answers given by the properties to survey questions, prepared for the study of strategic management tested by the Chi-square Test when the variables under analysis were measured on a nominal scale categorized into 
three or more groups or through the Fisher's Test (alternative to the Chi- square Test) when the nominal variables categorized into two groups.

Table 8. Chi-square test

\begin{tabular}{|c|c|c|c|}
\hline Partnership/Affiliation & $\mathbf{X}^{2}$ & p-value & $\mathbf{N}$ \\
\hline 1.1A- Is there a Standard Operational Procedures implementation strategy? & 70.001 & 0.000 & 114 \\
\hline 1.3A- How do you assess the SOP? & 4.612 & 0.103 & 80 \\
\hline $\begin{array}{l}\text { 1.5A- In which department do the Local Standard Operational Procedures and the Standard Operational } \\
\text { Procedures present themselves as being more useful? }\end{array}$ & 73.688 & 0.000 & 114 \\
\hline $2.2 \mathrm{~A}$ - Is there an aging analysis policy? & 31.64 & 0.000 & 113 \\
\hline 2.4A- How is it funded? & 46.184 & 0.000 & 107 \\
\hline 3.4A- What is the main criterion when selecting candidates? & 5.819 & 0.091 & 113 \\
\hline
\end{tabular}

The hypothesis that the typology of affiliation/partnership of the property influenced the strategic management survey questions measured in an ordinal scale was determined using the Kruskal Wallis test.

Table 9. Fisher's test

\begin{tabular}{|c|c|c|c|}
\hline Partnership/Affiliation & $\begin{array}{l}\mathrm{X}^{2} \\
\text { (Fisher) }\end{array}$ & p-value & $\mathbf{N}$ \\
\hline 1.2A- Are the SOP adjusted to local reality through Local Standard Operational Procedures? & 14.298 & 0.000 & 80 \\
\hline 1.4A- Do you use the results to improve the procedures? & 2.666 & 0.103 & 80 \\
\hline 1.1B- Do you use any kind of satisfaction survey of the external customer? & 22.922 & 0.000 & 114 \\
\hline 1.2B- Are the results obtained shared with the members of the executive management? & 5.612 & 0.018 & 114 \\
\hline 1.2B- Are the results obtained shared with the board? & 19.202 & 0.000 & 114 \\
\hline 1.2B- Are the results obtained shared with the staff? & 6.288 & 0.012 & 114 \\
\hline 1.2B- Are the results obtained shared with anyone? & 28.374 & 0.000 & 114 \\
\hline 2.1A- What is the "Funding" policy? & 14.906 & 0.000 & 114 \\
\hline $\begin{array}{l}\text { 2.3A- Is there any amount reserved from the net earnings for investments, modernization, furniture or } \\
\text { equipment? }\end{array}$ & 8.348 & 0.004 & 114 \\
\hline 2.5A- Do you usually carry out return on investment studies whenever a new investment is operationalised? & 12.377 & 0.000 & 112 \\
\hline 3.2A- Does the property have an employee satisfaction survey? & 7.776 & 0.005 & 113 \\
\hline 3.3A- Is there a defined recruitment and selection model implemented in the property? & 11.266 & 0.001 & 113 \\
\hline 4.1A- How is the company's promotional and marketing strategy managed? & 0.094 & 0.759 & 113 \\
\hline 4.2A- Is there an active guests' loyalty program? & 33.259 & 0.000 & 113 \\
\hline 4.3A- Does the hotel structure include a creative department? & 6.506 & 0.011 & 112 \\
\hline 4.2B- Is TV the main communication channel? & 0.091 & 0.763 & 114 \\
\hline 4.2B- Are magazines the main communication channel? & 27.95 & 0.000 & 114 \\
\hline 4.2B- Is radio the main communication channel? & 0.091 & 0.763 & 114 \\
\hline 4.3B- How is the property online presence managed? & 14.054 & 0.000 & 114 \\
\hline 4.4B- Does the property have an active presence on Instagram? & 0.390 & 0.532 & 99 \\
\hline 4.4B- Does the property have an active presence on Twitter? & 3.364 & 0.067 & 99 \\
\hline 4.4B- Does the property have an active presence on Pinterest? & 0.174 & 0.697 & 99 \\
\hline 4.5B- Does the property have a Newsletter? & 36.348 & 0.000 & 113 \\
\hline
\end{tabular}


Table 10. Kruskal Wallis test

\begin{tabular}{|c|c|c|c|}
\hline Partnership/Affiliation & \multicolumn{2}{|c|}{$K-W \chi^{2}(2)$} & p-value \\
\hline 1.3B- Is there a standard regarding the response timing to customers? & $\begin{array}{l}\text { No } \\
<\quad 30 \text { days } \\
30-40 \text { days } \\
>40 \text { days }\end{array}$ & 43.173 & 0.000 \\
\hline $\begin{array}{l}\text { 1.4B- How often are the results of the satisfaction survey discussed by members of the } \\
\text { executive management? }\end{array}$ & $\begin{array}{l}\text { Weekly } \\
\text { Monthly } \\
\text { Quarterly } \\
\text { Annually }\end{array}$ & 1.131 & 0.288 \\
\hline 2.6A- How do you classify the importance of the internal client in preparing the cash-flow? & $\begin{array}{l}\text { More important } \\
\text { Important } \\
\text { Moderately } \\
\text { important } \\
\text { Less important }\end{array}$ & 0.635 & 0.426 \\
\hline 2.6A- How do you classify the importance of the external client in preparing the cash-flow? & $\begin{array}{l}\text { More important } \\
\text { Important } \\
\text { Moderately } \\
\text { important } \\
\text { Less important }\end{array}$ & 0.308 & 0.579 \\
\hline 2.6A- How do you classify the importance of the "owners" in preparing the cash-flow? & $\begin{array}{l}\text { More important } \\
\text { Important } \\
\text { Moderately } \\
\text { important } \\
\text { Less important }\end{array}$ & 7.242 & 0.007 \\
\hline 2.6A- How do you classify the importance of the suppliers in preparing the cash-flow? & $\begin{array}{l}\text { Important } \\
\text { Moderately } \\
\text { important } \\
\text { Less important }\end{array}$ & 2.461 & 0.117 \\
\hline
\end{tabular}

The results showed that the typology of property affiliation/partnership significantly influenced the answers given (relative position adopted by the respondents in the ordinal scale) by the properties to the following questions in the questionnaire: "1.3B- Is there a standard regarding the response timing to customers?" and "2.6A- How do you classify the importance of the 'owners' in preparing the cash-flow?"

The differences found in these questions were significant $(\chi 2(2)=43.17 ; p=0.000$ and $\chi 2(2)=7.242 ; p=0.007)$, concluding that the properties of the type hotel chains showed significantly lower averages of the ordering levels of answers in the question that refers to response timing to the customer (less days) compared to the feedback of independent properties, with significantly higher averages of the ordering levels of answers on the importance of owners in the preparation of cash flow (less importance). 
Table 11. T-Student test

\begin{tabular}{|c|c|c|c|c|c|}
\hline & Partnership/Affiliation & $\mathbf{N}$ & Average & p-value & $\mathbf{F}$ \\
\hline \multirow{2}{*}{ 2.1B- What is the GOP in percentage terms? } & Hotel Chain & 73 & 24.890 & \multirow{2}{*}{0.467} & \multirow{2}{*}{0.037} \\
\hline & No & 40 & 22.950 & & \\
\hline \multirow{2}{*}{ 2.2B- What is the cost per occupied room of the rooms? } & Hotel Chain & 73 & 20.575 & \multirow{2}{*}{0.01} & \multirow{2}{*}{2.184} \\
\hline & No & 40 & 16.475 & & \\
\hline \multirow{2}{*}{ 2.2B- What is the cost per occupied room of the hotel total? } & Hotel Chain & 72 & 48.778 & \multirow{2}{*}{0.004} & \multirow{2}{*}{2.930} \\
\hline & No & 40 & 38.625 & & \\
\hline \multirow{2}{*}{ 2.3B- What is the room's profit margin? } & Hotel Chain & 73 & 65.603 & \multirow{2}{*}{0.110} & \multirow{2}{*}{0.124} \\
\hline & No & 40 & 63.025 & & \\
\hline \multirow{2}{*}{ 2.3B- What is the $\mathrm{F} \& \mathrm{~B}$ profit margin? } & Hotel Chain & 73 & 7.548 & \multirow{2}{*}{0.922} & \multirow{2}{*}{0.265} \\
\hline & No & 40 & 7.325 & & \\
\hline \multirow{2}{*}{ 3.1B- What is the average annual turnover of employees? } & Hotel Chain & 72 & 9.694 & \multirow{2}{*}{0.013} & \multirow{2}{*}{16.365} \\
\hline & No & 40 & 6.975 & & \\
\hline \multirow{2}{*}{ 3.2B- What is the property's headcount? } & Hotel Chain & 72 & 45.806 & \multirow{2}{*}{0.000} & \multirow{2}{*}{16.05} \\
\hline & No & 40 & 20.200 & & \\
\hline \multirow{2}{*}{ 3.3B- What is the annual average of the property's training hours? } & Hotel Chain & 50 & 28.600 & \multirow{2}{*}{0.182} & \multirow{2}{*}{1.808} \\
\hline & No & 24 & 15.625 & & \\
\hline \multirow{2}{*}{ 3.4B- What is the monthly average of absenteeism in the property? } & Hotel Chain & 72 & 7.236 & 0.01 & 8606 \\
\hline & No & 40 & 5.350 & 0.01 & \\
\hline $35 \mathrm{~B}-$ What is the average amount of comnensation for non-managers? & Hotel Chain & 72 & 712.64 & 0000 & $342+3$ \\
\hline . & No & 40 & 607.75 & 0.000 & 3.42 \\
\hline $35 \mathrm{~B}$ - What is the average amount of comnensation for managers? & Hotel Chain & 71 & 1003.4 & 0000 & 8117 \\
\hline 3.JB- What is the average amount of compensation for managers? & No & 39 & 790.00 & 0.000 & 8.117 \\
\hline $35 \mathrm{~B}$ - What is the average amount of comnensation for middle managers? & Hotel Chain & 72 & 860.83 & 0000 & 12369 \\
\hline & No & 28 & 720.36 & & \\
\hline $35 \mathrm{~B}$ - What is the average amount of comnensation for ton managers? & Hotel Chain & 71 & 1960.0 & 0000 & 4.479 \\
\hline 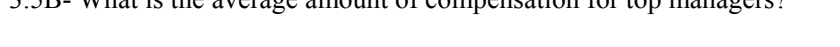 & No & 38 & 1283.9 & 0.000 & 4.4/9 \\
\hline $46 \mathrm{~B}$ - What nercentage of sales are related to leisure? & Hotel Chain & 74 & 32.135 & 0.000 & 5246 \\
\hline 4.6B- What percentage of sales are related to leisure? & No & 40 & 51.625 & 0.000 & 5.246 \\
\hline 4.6B- What nercentage of sales are related to business? & Hotel Chain & 74 & 65.527 & 0000 & 3.352 \\
\hline 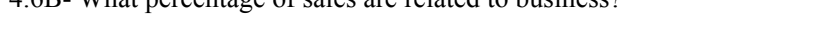 & No & 40 & 45.900 & & \\
\hline $46 \mathrm{~B}$ - What nercentage of sales are related to others? & Hotel Chain & 32 & 5.719 & 0049 & 0419 \\
\hline 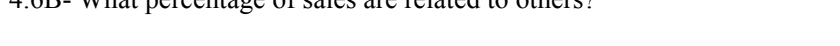 & No & 8 & 11.125 & 0.049 & 0.419 \\
\hline $47 \mathrm{~B}$ - What is the nercentage of sales ner sales channel. Internet? & Hotel Chain & 74 & 37.149 & 0024 & 9056 \\
\hline 4./B- What is the percentage of sales per sales channel: Internet? & No & 40 & 41.900 & 0.024 & 9.056 \\
\hline $47 \mathrm{~B}$ - What is the nercentage of sales ner sales channel. Walk In? & Hotel Chain & 72 & 8.903 & 0484 & 0115 \\
\hline . & No & 39 & 7.974 & 0.707 & 0.110 \\
\hline 47B- What is the percentage of sales per sales channel: Groun's site? & Hotel Chain & 74 & 29.811 & 0.000 & 27708 \\
\hline 4./D- What is the percentage or sales per sales crianner. Uroup s sile? & No & 40 & 21.275 & & 21.100 \\
\hline & Hotel Chain & 73 & 16.658 & & \\
\hline Agency/Tour Operators? & No & 40 & 23.625 & 0.000 & 0.225 \\
\hline (5) & No & 1 & 2.000 & & \\
\hline
\end{tabular}

The hypothesis that the property's affiliation/partnership typology influenced the answers given to the strategic management questionnaire measured on a numerical scale was analysed through the T- Student Test (Table 24). The results show that except for the questions "2.1B-What is the GOP in percentage terms?"; "2.3B- What is the F\&B and rooms profit margin?" "3.3B-What is the annual average of the property's training hours?"; "4.7BPercentage of sales per sales channel Walk In and Others", the other questions presented significant differences in the properties' feedback averages.

Thus, the averages of the answers of the hotel chain type in the remaining variables were significantly higher compared to the average of the answers of independent properties. 


\section{Conclusions}

The genesis of this research raises the issue of globalization as a starting point for the main issue focused by our analysis. Based on this socio-economic phenomenon that characterizes the postmodern society, we were interested in deepening the way of coexisting corporately in the hospitality sector, in a postmodern market marked by a high level of competitiveness, to a greater or lesser degree of profitability of socio-economic networks that assume themselves as one of the major features of contemporary society. The posture of the main players in this and other industries, with regard to their attitude towards the advantages that the network society allows, has been the subject of empirical research on many studies of the academy, some of which focused by the theoretical framework of this research (Enz, 2005; Enz et al., 2011; O’Neill \& Xiao, 2006; Conti \& Micera, 2005). The study carried out here makes a direct contribution with regard to the great fertility of this issue, and does not complete, not even close, what lies ahead so that there is a strong structured empirical and scientific knowledge in this field.

It is important to mention that the constant evolution of the socio-economic configuration of postmodern society launches a challenge to the academy when it comes to the many analysis opportunities likely to capture the attention of researchers, attracting to the scientific scrutiny of the dense web of interactions, which by their unprecedented nature originating in the contemporary society, still lack the study with regard to their origins, morphologies, consequences and mutabilities. It is precisely this context that was the focus of our study, isolating a very small part of the immense research opportunities that emerge in the context of today's hospitality sector, immersed in the technological, social and economic reality that characterizes post-modernity.

Networks, which are an unavoidable topic of our times, appear in this study as a key concept for understanding the competitive interaction among companies in the hospitality sector. Granovetter (1985) highlights the crosscutting nature of this concept that runs through the various areas of social life. The notion of network is present from the most basic family interaction to the densest corporate configuration. Grabher (2006) adds that networks have become a universal principle of social organization, and business companies were forced to recreate themselves, failing to act as mere isolated organisms, and becoming units composed of several links with the surrounding environment and their value chain formed by suppliers, competitors and strategic partners. The results measured in this study show that the networks provide the units with different competitive advantages, either through the affiliation in transnational structures, or through the adoption of other type of strategies that maximize the networks in which units are integrated within their surrounding context.

Thus, we sought to deepen, within the scope of the hospitality sector, the benefits and advantages of the organizational predisposition of units to maximize their interactions with the networks available in the surrounding context. One of the main manifestations of the concept at the level of the contemporary business environment inevitably consists of corporate management models that include the synergies of different production units. The hospitality sector is not at all an exception, which led to the formulation of starting questions that denote the direct comparison between the reality of the property integrated in the chain and its counterpart which exists thanks to its autonomous individual operation. On the one hand, there is empirical evidence that point to the units integrated in corporate structures as having better performance on the market (O'Neill \& Xiao, 2006; O'Neill \& Mattila, 2004; Damonte et al., 1997), although on the other hand, different research advocate that autonomous units have characteristics that allow for a superior performance in terms of results (Miyeal, 2006; O'Neill \& Carlback, 2011; Rushmore, 2004). Also with the focus on the hotel units performance, Israeli (2002) supports a different perspective on the grounds that the oscillations in their performance are directly related both to their ability to set higher prices and the quality classification they feature.

However, the consensus on the performance of hotel units increases exponentially when the subject lies in the influence played by the strategic management model adopted by business organizations of the hospitality sector on their results. Here, different authors (Yeung \& Lau, 2005; Lee \& Jang, 2007; Gursoy \& Swanger, 2007) have carried out empirical studies, reaching findings that strongly support the idea in question.

One of the first evidence to be highlighted regarding the sample characteristics of this research is that the properties of greater accommodation capacity tend to have affiliation with renowned brands/chains, as well as most of the classifications of a superior nature. This fact, observed in this study of sampled units in the city of Lisbon, gathers the premises studied by Israeli (2002) on the hospitality industry in Israel. According to the author, the literature indicates that whether the quality classification system according to stars or the affiliation in a renowned international brand are perceived as enhancers of a better performance, measured by the author through the ability to practice higher prices. If, on the one hand, the empirical evidence found by Israeli (2002) only supports the side of the classification according to stars as a differentiation factor of the results, it is interesting to note that the sample of this study reveals that affiliation in hotel chains and the presentation a high quality 
classification are elements that appear in close proximity. In fact, the analysis that crossed units with differences in quality classification showed, with regards to the strategic management paradigm, different concerns at several levels, such as the existence of procedure standards and the importance the existence of these standards has for the operation, the concern for the guest's feedback, as well as their follow-up, application of employees satisfaction surveys, the use of a defined employees selection model, employees turnover, and online presence management. In short, the cited indicators from different areas of hospitality operation point to a more robust and active strategic management by the units with higher quality classifications regarding the dimensions of the Balanced Scorecard than the units that have lower quality classifications. Thus, there is a well distinct approach by the units with different quality classifications, which could influence the performance oscillations measured by the research carried out by Israeli (2002). However, if the author does not reach conclusive results regarding the perception of the hotel units affiliation in renowned brands as a factor that enhances higher performance, this research concludes that there are significant differences between units affiliated and unaffiliated in international hotel groups with regards to their strategic management approaches. This fact suggests different levels of optimization of network reality in the coexistence with a competitive market.

One of the first findings in this scope relates to the use of standard operational procedures, whose existence is predominant in integrated units. This aspect could possibly report the added value that a property gets by integrating an international hotel structure. The standard procedures that allow for the consistency and the quality of processes, which are the result of the experience of the operation of several hotel units for many years, by being almost instantly replicated in a given property, provide an undeniable advantage. This was positively correlated, combined with other factors, to higher values at the level of occupation by O'Neill and Carlback (2011), Apfelthaler and Vaimen (2012). Through their analysis of the literature on business internationalization processes of the tertiary sector, these authors point out the need of knowledge acquisition as one of the factors that drive organizations to cross the borders of the local market and internationalize. The internationalization through the incorporation in multinational chains, in addition to the convenience it entails and the ability to neutralize much of the risks of entering new markets, enables the addition of knowledge capital quite rapidly and comfortably. A reality which is characterized by the existence of a more fluid access to a body of know-how related to business processes, giving the units benefiting from it a seemingly superior consistency with respect to this matter. This is also reflected on the dimension of the external satisfaction survey in the sharing of results and customer responses, a core process to get information on what pleases the guest and what should be corrected and improved in terms of service. This allows, according to Jang (2008) and Gruber et al. (2009), expressing to the customers how much they are valued by the organization and the important role they plays in improving the processes of an entity that accepts his input. According to Waterhouse (2012), this fact becomes crucial when it comes to guest retention, which, in the opinion of Karatepe (2006, cit. by Waterhouse, 2012), is, in economic and marketing terms, much less expensive and time consuming than attracting new customers to the business organization. However, it is important to mention the emerging phenomenon of client to client feedback online platforms (Kotler \& Keller, 2011). The important online exchange of information among guests and potential customers of the hotel units can provide valuable ideas the management team of non-integrated units that do not have structured guests survey processes. This collection of information may result in the optimization of processes, in problem solving and in a follow-up contact with a guest with a view to retain him. This informal strategy may now be an alternative to obtain information to traditional standard processes whose cost and time consumption are possibly higher. Also with significant differences in the sharing of the external customer satisfaction survey results, the integrated units are the ones that show they have a more robust internal communication reality, with results superior to the independent units at the level of sharing, either with members of the executive committee or with the administration of the units, or with the employees in general. Through a study carried out specifically in the hospitality sector, O'Neill and Mattila (2004) argue empirically that hotel brands with higher levels of guest satisfaction tend to achieve higher earnings and higher growth rate specifically on accommodation revenue. The response to customers is a central topic in their satisfaction, already extensively focused on literature (Huppertz, 2007; Kim, Wang, \& Mattila, 2010; Orsingher, Valentini \& Angelis, 2009; Rio-Lanza, Vazquez-Casielles, \& Diaz Martin, 2009; Susskind \& Vaccari, 2011; Yavas et al., 2008). The consistency in the procedures of response to guest's feedback, whether in complaint format or by return of opinion surveys, is crucial to their loyalty (Waterhouse, 2012). Thus, this is another indicator of the optimization level that the organization carries out by default of the social fabric in network involving the hotel unit. By practicing a standardization regarding guest input maximization processes, the business organization improves its operational procedures and adapts the service to the target it wishes to attract, thus making it possible for the product to become more profitable and competitive. Again it should be noted that the lack of standard procedures at independent hotel units does not automatically mean that they do not apply more discretionary strategies to get the valuable guest feedback. This 
may occur, as already mentioned, with a proximity to several online platforms that do not have additional costs and may enable to obtain information and follow up problems guests experienced during their stay in order to enhance guest loyalty. However, the procedural standardization of this more informal proximity may eventually benefit the property by giving consistency to this practice. Thus, we would be in the presence of guest survey processes with relevant levels of efficiency regarding their costs and results. This fact gives clues on a possible emerging paradigm that is challenging the efficiency of various existing robust processes in properties affiliated in multinational companies of consolidated reputation. Here, in a perspective that is more focused on guest feedback after their stay, we find a new possibility that allows simultaneously not only becoming aware possible opportunities for improvement of the product in the case of negative feedback, as well as maximizing positive comments to attract other guests because this dynamic has a public nature. The fact that these platforms come to fully substitute for the quality and effectiveness of traditional guest survey processes is not a foregone conclusion, but they are certainly present an alternative reality eventually more profitable for independent units.

One other fact that is visible in the results of this study relates to the management of online presence, which is an increasingly important topic nowadays. In general, the management of the online presence of the different properties varied according to their nature of affiliation, and most of the independent units tend to outsource this process. Yet, the management of online presence has faced several reformulations, and today, the importance of third parties with regards to visibility emerges. If it is true that a corporate website of a given large multinational chains provides a high-level visibility to its affiliated properties, currently the presence in specialized search engines is already unavoidable, as is clearly shown by the research carried out by Guo et al. (2013).

In short, the successive analyzes of indicators conferred by the strategic management survey in the hospitality sector based on the Balanced Scorecard dimensions (Kaplan \& Norton, 1996) respond positively to the initial question: "Do the strategic management practices of independent units feature significant differences when compared to the strategic approach used by international hotel chains?" There are significant differences between the positioning of strategic management of affiliated hotels in hotel groups and autonomous units of independent management. This is extremely important in view of the postulate of authors like Lee and Jang (2007), Yeung and Lau (2005), Gursoy and Swanger (2007) and Sainaghi (2010), who claim that the strategic management approach presents itself as a prominent factor in terms of the influence it has on the units' performance and the results they reach.

However, the analyses of core indicators for measuring the performance of the properties, such as the GOP, or the rooms or F\&B profit margin, showed no significant difference at the level of the statistical tests to which they were submitted. This fact does not allow us to directly confirm the studies that support the superiority of integrated units versus independent units, such as is the case of Mattila and O'Neill (2004), which, with their empirical testing, obtained evidence that pointed to a greater ability to generate revenues and occupation by the units integrated in hotel chains.

In addition, O'Neill and Xiao (2006) gathered evidence on this financial dimension that places the net operating income and the average daily rate of the integrated units at a higher level when compared to that of the independent units, with the exception of the budget and luxury accommodation segments. Through their research work, Enz and Canina (2011) add that in the first six months, the franchising hotel units sampled, which had full service products, got better results than those presented by the independent units. However, as previously mentioned, the evidence of this research does not support the linear superiority of units included in transnational chains regarding the results presented by the financial indicators analyzed. In addition to that, Enz and Canina (2011) also show that one of the most interesting facts present in the results of their research relates to a sector of the study sample: limited service independent units. Such units presented results in no time inferior to the results of the international brand franchising units that had a know-how structure and a set of other amenities provided by the organizations of which they were part. In addition to not having lower results, from the first six months, these independent units showed higher results than the integrated ones. The authors suggest that this superiority may eventually derive from a higher pricing strategy and more appropriate to the local level. The authors also risk that such units may eventually maximize the potential of the surrounding social network in an innovative manner. Obtaining know-how, through existing players on the unit's external interactions network, may be a more efficient and less expensive way to get the knowledge required. From this perspective, it is relevant to note the fact that the results of this research show that the maximization form of the network society carried out by the units integrated in multinational structures provides various strong advantages in many aspects of the hotel operation here analyzed through the Balanced Scorecard paradigm point of view. However, the results also suggest, in line with Enz and Canina (2011), that there are enough positive data from several independent units that, with regard to several indicators, show the existence of differentiated realities that are also competitive. In this way, we may risk the 
premise that these units begin to draw strategies to maximize the reality network that are an alternative to the strategies long formalized by the large multinational chains and their large organizational structures, which provide a protectionist environment with regard to business risks, and address the lack of specialized know-how.

These alternative strategies will eventually involve innovative partnerships with the unit value chain. They allow for a cost management that is much more efficient than the one by the integrated units since when these purchase the benefits of the affiliation, they invariably spend high fixed amounts on knowledge and processes global platforms, regardless of their specific needs. This fact, combined with light-oriented operation models which are based on the use of strategies such as outsourcing various services necessary for the operation, may eventually be the keys to the survival of independent units in an increasingly competitive market that has increasingly less margin for less efficient or less profitable business processes.

In short, most of the indicators analyzed in this research point to the integrated units as having a superior performance in the majority of the dimensions that make up the strategic management model, drawn from the Balanced Scorecard (Kaplan \& Norton, 1996) to those of the independent units that were part of the sample under study. This reality easily discloses the formalized maximization of the economy of scale carried out by the units integrated in hotel chains, benefiting both from the know-how and the corporate partnerships to optimize their processes and results. This fact goes against the evidence presented by Enz and Canina (2011) who found that in the first years of operation with regard to results of independent hotels, the affiliates in some kind of brand obtained better results thanks to a higher occupancy. However, it is relevant to mention that the statistical analysis carried out did not find significant differences between the two typologies of hotel unit, with respect to key performance indicators in the assessment of results of any unit, such indicators are the rooms and F\&B profit margin, and the results in terms of Gross Operating Profit. This fact also confirms empirical data provided by Enz and Canina (2011) in whose study the performance of several independent chains showed superior results compared to the results obtained by units affiliated facilities in multinational chains.

In short, the data revealed in this study are in line with the rapid development of tourism and the sector, and the affiliation of units in transnational hotel groups has been one of the typical phenomena of this industry's reality in recent decades. This development has gained strength due to its ability to provide hotel units with a global structure in a reasonably quick and comfortable way as Léon-Darder et al. (2011) explain, seeking to provide the hotel units with a maximization ability of the existing networks in the social corporate context. The search for know-how, strategic partnerships, prestige and guest attractiveness ability motivated and continue to motivate several hotel properties to incorporate into groups that provide solutions to their challenges and enable the much-desired international presence, developing consistent and uniform business processes as identified by Whitla et al. (2007). The alleged disadvantages that arise against the affiliation in multinational chains solution, such as the property's loss of identity or management autonomy, are already overcome by affiliation strategies that preserve both the property's characteristics and its management autonomy, while giving access to loyalty platforms, reservations systems and visibility in the market that they would hardly reach otherwise. Nevertheless, we also observe the subsistence of hotel units, in an independent reality, that coexist competitively in a market populated by hotels affiliated in major international brands. The empirical evidence reached by this study clearly shows that if in the Balanced Scorecard matrix the robustness of the affiliated units gives an alleged superiority in their strategic management practices and operational dimension, when it comes to the financial indicators significant differences between the various units are not distinguished and there are no significant differences among the units, with or without affiliation. Whitla et al. (2007) argue that the demand of the professional traveller has as a priority criterion, in the selection of hotel units, their presence in a wide geographical span.

However, the authors also claim that the importance of the guests with local origin must also be taken into account, as well as the many international travellers who prefer a genuine accommodation experience that reflects the peculiarities of the destination where it is located. It is redundant to recall the advantages of independent units in this chapter by not having most of the constraints that affiliated units have with regard to the adoption of strategies to make the guest experience the most genuine and locally anchored as possible. Moreover, if the social reality in network presents itself as an unavoidable paradigm in today's business world, regardless of the sector concerned, it is important to deepen the existing empirical knowledge on the alternative strategies that independent units have made emerge to achieve the advantages that the units integrated in multinational hotel chains have by default, but this time with more streamlined costs, more efficiently adjusted to the real needs of the independent units operation. The clear higher maximization of the network reality by units affiliated in international groups seems therefore to give an unquestionable operational robustness that, according to the empirical evidence provided by the units sampled in this study, did not, however, constitute a distinct competitive advantage in terms of financial indicators. This fact suggests that the independent hotel units have competitiveness sources that move away from the 
traditional paradigm of the network reality profitability. In an increasingly competitive market, there are more and more managers opting for alternatives to the high fixed cost structures that, traditionally, the international brands entail. The emerging alternative options are challenging the traditional view and the cost-benefit of this coexistence in a network that may become costly and challenging with regard to the reality of a hotel unit that starts operating from scratch. This rapid evolution of the hospitality industry democratizes some of the previously exclusive privileges of affiliated properties. If this scenario, on the one hand, can enhance the sustainability of the independent nature of the autonomous units, on the other, it will become a challenge in the medium/long term to be taken into account by the major hotel groups, mainly those whose strategies are based on management or franchising contracts and therefore, and because of that, involve high cost structures. This challenge may eventually lead to the need for reinvention of the business models of medium and large hotel groups in order to ensure the maintenance of interest from the hospitality industry players in the affiliation process.

\section{Limitations and Future Research Lines}

As a conclusion of this study, we can see that several goals have been achieved in order to draw a clearer image of the interactions among the hotel units and the network society that characterizes our days. The Balanced Scorecard paradigm (Kaplan \& Norton, 1996) made it possible to compare two of the main realities of hotel management - affiliation in brands or independent management-in a holistic manner using the major dimensions of a unit's life. This macro view was based on different indicators that allowed comparing several characteristics among independent and integrated units, which offers more comprehensive and, therefore, more general empirical evidence. One of the advantages of this scenario is unquestionably to facilitate the interpretation and application of acquired knowledge, easily crossing the border between the theoretical and the practical. However, it should also be noted that each dimension addressed in this study, each criterion mentioned, may be the target of a segmented attention that will allow undoubtedly a more fertile depth to each of the aspects compared. The intersection of a significant number of elements under analysis may easily omit various aspects of possible importance that a more edgy, and therefore, less comprehensive study may identify.

In addition to the wide configuration of this research, it is still necessary to consider that the selected sample consisted exclusively of units located in Lisbon, where the dominant segments are the leisure and business. Thus, the characteristics of the properties studied are necessarily in accordance with this bipartite reality and highly targeted to a specific guest profile, which may condition the wealth of results. In addition to this bipartite reality of business segments, the sample size may also be optimized in future research in order to have greater robustness, which will enable a higher degree of statistical security in the assessment of evidence obtained. The inclusion of a greater number of hotel units in the nature of the sample will certainly be useful in the replication of studies in this research line. On the other hand, the non-inclusion of hotels with a classification below two stars, or even the exclusion from the sample of hotels with other features as apart-hotels or others, may eventually be overcome in future work which will possibly result in new perspectives under the comparative analysis between independent units and units affiliated in hotel groups. Since this study obtained relevant data regarding the degree of profitability of the network reality, both by independent units and by the units integrated in hotel chains, it is appropriate to extend the sampling scope to regions differing from the national reality and even samples from across the border regions, in order to verify the extent to which the tourism product offered or the target guest profile will influence the results of the comparative analysis.

As mentioned, some of the most prevalent financial indicators cited in this study, when compared between the two property typologies in question, did not reveal any significantly relevant statistical differences. This fact may be the subject of an in-depth focus, which, through more centred on the financial dimension, will scrutinize the issue with stronger robustness.

If the comparison between integrated and independent hotel units may here be somehow conditioned by factors inherent to the size of the national economy, the relevance of a sample that integrated units of different countries becomes indisputable. Thus, by integrating multiculturalism as characteristic of the study, we might analyse to what extent the results measured by comparing the indicators coming from the various dimensions are or are not of a transnational nature.

\section{References}

Alon, I., Ni, L., \& Wang, Y. (2012). Examining the determinants of hotel chain expansion through international franchising. International Journal of Hospitality Management, 31(2), 379-386. http://dx.doi.org/10.1016/j.ijhm.2011.06.009

Barney, B. (1991). Firm resources and sustained competitive advantage. Journal of Management, 17(1), 99-120. http://dx.doi.org/10.1177/014920639101700108 
Bartlett, C., \& Ghoshal, S. (2002). Managing Across Borders: The transnational solution. London: Century Business.

Buhalis, D., \& Costa, C. (2006). Tourism Business Frontiers, consumers, products and industry. Amsterdam: Elsevier.

Castells, M. (1999). L'Ère de l'Information - Le Pouvoir de l'Identité. Paris: Fayard.

Chen, J., \& Dimou, I. (2005). Expansion strategy of international hotel firms. Journal of Business Research, 58(12), 1730-1740. http://dx.doi.org/10.1016/j.jbusres.2004.11.001

Chesbrough, H., \& Rosenbloom, R. (2002). The role of the business model in capturing value from innovation: Evidence from Xerox Corporation's technology spin-off companies. Industrial and Corporate Change, 11, 529-555. http://dx.doi.org/10.1093/icc/11.3.529

Conti, C., \& Micera, R. (2005). Hotel governance structure and alliances in the tourism industry. 14 International Leisure and Tourism Symposium ESADE, Saló Internacional del Turisme.

Crossan, M., \& Berdrov, I. (2003). Organizational learning and strategic renewal. Strategic Management Journal, 24(11), 1087-1105. http://dx.doi.org/10.1002/smj.342

Crotty, J. (2008). Structural Causes of the Global Financial Crisis: A Critical Assessment of the New Financial Architecture. Political Economy Research Institute (PERI) Working Paper no. 180.

Cunill, O. (2006). The Growth Strategies of Hotel Chains-Best Business Practices by Leading Companies. Oxford: The Hawoeth Hospitality Press.

Daft, R. (1983). Organization Theory and Design. New York: West.

Damonte, T., Rompf, D., Domke, J., \& Bahl, R. (1997). Brand affiliation and property size effects on measures of performance in lodging properties. Hospitality Research Journal, 20(3), 1-16. http://dx.doi.org/10.1177/1096348004264081

Enz, A. (2005). Hospitality Strategic Management-Concepts and Cases. New Jersey: John Wiley \& Sons Inc.

Enz, A., \& Canina, L. (2011). A Comparison of the Performance of Independent and Franchise Hotels: The First Two Years of Operation. Cornell Hospitality Report, 11(21).

Evans, N. (2015). Strategic Management for Tourism, Hospitality and Events. New York: Routledge.

Gallo, M., \& Krupka, B. (2008). Understanding the golden segments for driving growth under uncertainty. Innovation in the travel \& tourism Industry. New York: Daemon Quest.

Grabher, G. (2006). Trading routes, bypasses, and risky intersections: Mapping the travels of networks between economic sociology and economic geography. Progress in Human Geography, 30(2) 1-27. http://dx.doi.org/10.1191/0309132506ph600oa

Granovetter, M. (1985). Economic action and social structure: The problem of embeddedness. American Journal of Sociology, 91, 481-501. http://dx.doi.org/10.1086/228311

Grant, R. (1996). Prospering in Dynamically-Competitive Environments: Organizational Capability as Knowledge Integration. Organization Science, 4(7), 375-378. http://dx.doi.org/10.1287/orsc.7.4.375

Gruber, T., Szmigin, I., \& Voss, R. (2009). Handling Customer Complaints Effectively-A Comparison of the Value Maps of Female and Male Complainants. Managing Service Quality, 19(6), 636-656. http://dx.doi.org/10.1108/09604520911005044

Gursoy, D., \& Swanger, J. (2007). Performance-enhancing internal strategic factors and competencies: Impacts on financial success, International Journal of Hospitality Management, 26(1), 213-227. http://dx.doi.org/10.1016/j.ijhm.2006.01.004

Hannan, T., \& Freeman, J. (1989). Organizations and Social Structure. Organizational Ecology. Cambridge: Harvard U. Press.

Holjevac, I. A. (2003). A vision of tourism and the hotel industry in the 21 st century. International Journal of Hospitality Management, 22, 129-134. http://dx.doi.org/10.1016/S0278-4319(03)00021-5

Israeli, A. (2002). Star Rating And Corporate Affiliation: Their Influence On Room Price And Performance Of Hotels In Israel. Hospitality Management, 21, 405-424. http://dx.doi.org/10.1016/S0278-4319(02)00037-3

Kaplan, R., \& Norton, D. (1996). The Balanced Scorecard: Translating strategy into action. Boston: Harvard Business School. 
Lee, J., \& Jang, S. (2007). Market diversification and financial performance and stability: A study of hotel companies. International Journal of Hospitality Management, 26(2), 362-375. http://dx.doi.org/10.1016/j.ijhm.2006.02.002

Léon-Darder, F., Villar-Garcia, C., \& Pla-Barber, J. (2011). Entry mode choice in the internationalisation of the hotel industry: A holistic approach. The Services Industries Journal, 31(1), 107-122. http://dx.doi.org/10.1080/02642069.2010.485198

Mahalik, D., \& Satpathy, B. (2011). Prioritization of outsourcing in hotel industry: A fuzzy AHP criteria decision making. South Asian Journal of Tourism and Heritage, 4(2), 110-119.

Metcalfe, S. (2005). Innovation, Competition and Enterprise: Foundations for Economic Evolution in Learning Economies. University of Manchester, Centre for Innovation and Competition, Discussion paper 71.

Mieyal-Higgins, S. (2006). Independent relish individuality. Hotel \& Motel Management, 221(21), 1-38.

O'Neill, J., \& Carlback, M. (2011). Do brands matter? A comparison of branded and independent hotels' performance during a full economic cycle. International Journal of Hospitality Management, 30, 515-521. http://dx.doi.org/10.1016/j.ijhm.2010.08.003

O'Neill, J., \& Xiao, Q. (2006). The Role of Brand Filiation in Hotel Market Value. Cornell Hotel and Restaurant Administration Quarterly, 1(47), 1-14. http://dx.doi.org/10.1177/0010880406289070

O'Neill, J. W., \& Mattila, A. S. (2004). Hotel branding strategy: its relationship to guest satisfaction and room revenue. Journal of Hospitality \& Tourism Research, 28(2). 156-165. http://dx.doi.org/10.1177/1096348004264081

Phillips, P., \& Louvieris, P. (2005). Enterprises: A Balanced Scorecard Perspective Performance Measurement Systems in Tourism, Hospitality, and Leisure Small Medium-Sized. Journal of Travel Research, 44, 201-211. http://dx.doi.org/10.1177/0047287505278992

Pla-Barber, J., \& Ghauri, P. (2012). Internationalization of service industry firms: understanding distinctive characteristics. The Service Industries Journal, 32(7), 1007-1010. http://dx.doi.org/10.1080/02642069.2012.662498

Porter, M. (1999). On Competion. Boston: Harvard Business School Press.

Rio-Lanza, A., Vazquez-Casielles, R., \& Diaz-Martin, A. (2008). Satisfaction with service recovery: Perceived justice and emotional responses. Journal of Business Research, 62, 775-781. http://dx.doi.org/10.1016/j.jbusres.2008.09.015

Rosnay, J. (1975). Le Macroscope: Vers une vision globale. Paris: Ed. Seuil.

Rushmore, S. (2004). A case for being independent. Hotels (February), 22.

Sainaghi, R. (2010). Hotel performance: State of the art. International Journal of Contemporary Hospitality Management, 22(7), 920-952. http://dx.doi.org/10.1108/09596111011066617

Sainaghia, R., Phillips, P., \& Cortia, V. (2013). Measuring hotel performance: Using a balanced scorecard perspectives' approach. International Journal of Hospitality Management, 34, 150-159. http://dx.doi.org/10.1016/j.ijhm.2013.02.008

Shiller, R. (2008). The Subprime Solution: How Today's Global Financial Crisis Happened, and What to Do about It. New Jersey: Princeton University Press.

Stonehouse, G., Hamill, J., Campbell, D., \& Purdie, T. (2004). Global and Transnational Business: Strategy and Management. Chichester: Wiley.

UNWTO. (2011). Tourism Highlights. Retrieved from http://www.unwto.org

UNWTO. (2012). Tourism Highlights. Retrieved from http://www.unwto.org

UNWTO. (2013). Tourism Highlights. Retrieved from http://www.unwto.org

Whitla, P., Walters, P., \& Howard, D. (2007). Global Strategies in the International Hotel Industry. Hospitality Management, 26, 777-792. http://dx.doi.org/10.1016/j.ijhm.2006.08.001

Yeung, P. K., \& Lau, C. M. (2005). Competitive actions and firm performance of hotels in Hong Kong. International Journal of Hospitality Management, 24(4), 611-633. http://dx.doi.org/10.1016/j.ijhm.2005.06.005

Zahra, A., \& George, G. (2002). Absorptive capacity: A review, reconceptualization, and extension. Academy of 
Management Review, 27, 185-203. http://dx.doi.org/ 10.5465/AMR.2002.6587995

\section{Copyrights}

Copyright for this article is retained by the author(s), with first publication rights granted to the journal.

This is an open-access article distributed under the terms and conditions of the Creative Commons Attribution license (http://creativecommons.org/licenses/by/3.0/). 